and in a good light and the child must be given adequate time to respond.

Since the primary need is to discover the child's everyday visual capacity at home, in the street, and in the classroom, the examiner may consider it advisable to begin by testing for distance with both eyes uncovered, lest the child will not accept monocular occlusion. If possible, however, each eye should be tested separately for distant and for near vision, with completely effective occlusion of the other eye, at the first interview.

Every child's manner of response is different and clinically most revealing so that the medical examiner would be wise to carry out the test personally or closely observe its application by an experienced assistant.

\section{Later Extension of Testing Materials}

The portable pack was originally designed for screening of children only, but its potentialities in the testing of foreign or illiterate adults soon became apparent to workers in hospital ophthalmological outpatient departments. Finding that the number of letters provided, particularly those of the larger sizes, were too few for their particula purpose and that the cards were too flimsy to withstand the hard usage to which they were subjected, orthoptists began to reques a bigger selection of letters, spongeable plasticized cards, and stronger hinges.

Consequently, two blocks of single-letter cards were prepared, comprising respectively three letters of each size from $6 / 60$ to $6 / 18$ inclusive and three letters of each size from $6 / 18$ to $6 / 6$ inclusive (the overlapping at $6 / 18$ was deliberate). A near-vision block of cards containing to the page at least six letters of each size from $6 / 60$ to $6 / 6$ (reduced Snellen) and N 18 to N 5 (reduced roman) were also provided. In response to further demand an entirely new block of $6 / 6$ to $6 / 3$ letters for testing at 10 ft. $(3 \mathrm{~m}$.) was added to the series-that is, three letters each of sizes $6 / 6,6 / 5,6 / 4$, and $6 / 3$. Eventually, a panel chart $(6 / 60$ to $6 / 6)$ for illumination in standard boxes was also prepared as was, in response to special request, a similar blank panel on which separate letters printed on Perspex squares: can be hooked. Recently, a request from continental sources for permission to prepare lantern slides for projection has been received. M.D.S. has also found a cube with interior flashlamp illumination useful in nurseries and infant schools where ordinary lighting is inadequate

\section{COMMENT}

We are aware of the limitations as well as the advantages of this testing material. The letters used have been specially selected for easy visual recognition. But the inequality of difficulty in letter recognition is an inescapable problem for the designers of all letter charts. This subject has been admirably discussed by Bennett (1965). We have insufficient personal experience in applying the material to large numbers of normal and visually impaired adults to refute the frequent criticism that tests employing single letters or widely spaced letters are not always effective for the detection of the less severe forms of unilateral amblyopia. To some extent this is overcome by the use of the panel chart, but at the expense of portability. We can, however, say that this particular objection is invalid with regard to normal children under 7 years and handicapped children of comparable mental age; since, in M.D.S.'s experience, at this developmental stage they are characteristically impelled to concentrate on visual fixation of each letter on the chart as a separate entity, just as they are impelled when first learning to read previously un seen prose material to concentrate (with eyes, voice, and index finger) on single words in a sentence. The obvious solution to any doubt in this connexion, however, is for the examiner to record clearly the name of the test, the distance, and the results obtained, including, if necessary, a brief comment on the manner of performance. When used in this way the test has proved itself practical, informative, and repeatable.

Most young children greatly enjoy themselves during the test. Because it bears a positive relation to standard methods of testing visual acuity, transition to these methods is eased for handicapped children as their understanding and levels of scholastic performance improve. It also provides an acceptable link with conventional testing procedures for shy, inarticulate, or embarrassed normal children.

The Sheridan-Gardiner test materials are obtainable from Messrs. C. Davis Keeler, 21 Marylebone Lane, London W.1.

The Stycar vision tests are obtainable from the National Foundation for Educational Research, The Mere, Upton Park, Slough, Bucks.

M.D.S. is in receipt of a grant from the Medical Research Council.

\section{REFERENCES}

Bennett, A. G. (1965), British fournal of Physiological Optics, 22, 238.

Gardiner, P. A. (1967). British fournal of Ophthalmology, 51, 469.

Gardiner, P. A., and Joseph, M. (1968) Developmental Medicine and Child Neurology, $10,42$.

Pugmire, G. E., and Sheridan, M. D. (1957), Medical Officer, 98, 53.

Sheridan, M. D. (1960). British Medical fournal, 2, 453 .

Sheridan, M. D. (1969a). In Aspects of Developmental and Paediatric Ophthalmology, edited by P. A. Gardiner, R. C. MacKeith and V. Books. p. 39. London, Heinemann Medical Books.

Sheridan, M. D. (1969b). Manual of Instruction for Stycar Vision Tests, 2nd ed. Slough, National Foundation for Educational Research. Wybar, K, and Harcourt, B. (1968). Archives of Disease in Childhood, 43, 658.

\title{
Simple Instrument for Testing the Sense of Taste
}

Dr. M. A. H. ROBERTSON, senior registrar in neurology, Dundee Royal Infirmary, writes: When a piece of copper and a piece of zinc, held together at one end, have their free ends. applied to the tongue a bitter sour taste is experienced. This well-known phenomenon is an elementary demonstration of the voltaic cell.

A leaf of copper and one of zinc, each 3 in. long by $\frac{1}{2}$ in. wide by $4 / 1000$ in. thick $(7.6 \mathrm{~cm}$. long by $1.3 \mathrm{~cm}$. wide by $0.1 \mathrm{~mm}$. thick), placed in flat opposition to one another and soldered at one end, form a broad malleable forceps whose proportions are convenient for sandwiching the right or left edge of the protruded tongue. Preliminary studies have shown that an equally effective stimulus can be delivered simply by holding the two leaves of metal together and pressing their common edge against the tongue. Allowing the patient to hold the instrument and test himself allays apprehension and improves perception.

The instrument has the following electrical properties: theoretical current $0.625 \mathrm{~mA}$; measured maximum current $0.45 \mathrm{~mA}$, falling to $0.22 \mathrm{~mA}$ after one or two seconds due to polarization; normal current $0.4 \mathrm{~mA}$ falling to $0.2 \mathrm{~mA}$. The peak current can be re-established by wiping the plates or moving the plates on the tongue. The maximum voltage appears to be $\mathbf{0 . 5 5}$.

Monrad-Krohn (1964), in describing the technique for testing galvanically the sense of taste, recommended a current of $0 \cdot 2-0.4$ $\mathrm{mA}$. Peiris and Miles (1965), using the electrogustometric method of Krarup (1958) in their study of Bell's palsy, observed that in $90 \%$ of their cases the threshold of appreciation on the normal side of the tongue was $0.03 \mathrm{~mA}$ or less.

This simple instrument, with its advantages of compactness, intrinsic power supply, and ease of use, recommends itself as a clinical tool.

I wish to thank Mr. A. R. Rimmer and Mr. W. Fyffe, of the Regional Physics Department, for their technical assistance.

REFERENCES

Krarup, B. (1958). Acta Oto-laryngologica, 49,

Monrad-Krohn, G. H. (1964). The Clinical Examination of the Nervous System, 12th ed. London, Lewis.

Peiris, O. A., and Miles, D. W. (1965). British Medical fournal, 2, 1162 . 